\title{
A Traditional Turkish Fermented Non-Alcoholic Grape-Based Beverage, "Hardaliye"
}

\author{
Fatma Coskun
}

Food Engineering Department, Agricultural of Faculty, Namık Kemal University, 59030 Tekirdag, Turkey; fcoskun@nku.edu.tr; Tel.: +90-282-250-21-62; Fax: +90-282-250-99-54

Academic Editor: Shao Quan Liu

Received: 15 November 2016; Accepted: 20 December 2016; Published: 1 January 2017

\begin{abstract}
Hardaliye is a non-alcoholic fermented beverage produced in a traditional way in Thrace, the European part of Turkey. The nutritional value of hardaliye is derived from the grapes and the fermentation process. Health benefits of hardaliye are also related to etheric oils present in mustard seeds. Hardaliye is a lactic acid fermented traditional beverage produced from grape juice and crushed grapes with the addition of different concentrations of whole/ground or heat-treated mustard seeds and sour cherry leaves. The color of hardaliye reflects the original color of the grapes and has a characteristic aroma. Dark red grape is preferred. Benzoic acid is used as preservative during production. Benzoic acid inhibits or decreases alcohol production by affecting the yeast. Fermentation occurs at room temperature for 7-10 days. If the ambient temperature is low, fermentation process can be extended until 20 days. Once fermented, the hardaliye is stored at $4{ }^{\circ} \mathrm{C}$ for three to four months. The hardaliye is consumed either fresh or aged. If it is aged, hardaliye may contain alcohol. The industrial production is just in small-scale and it must be developed. More studies are required to determine characteristic properties of hardaliye. Identification of the product properties will supply improvement for industrial production.
\end{abstract}

Keywords: hardaliye; fermented beverage; mustard seeds

\section{Introduction}

All over the world, there is an increasing interest in traditional fermented products. In many regions of Turkey, there are many different traditional fermented foods produced from products of a particular region. Hardaliye is a fermented beverage produced in a traditional way in Thrace, the European part of Turkey [1]. Hardaliye is a valuable, beneficial traditional beverage that is consumed with pleasure and has been produced for centuries. Grape is not available in winter. Hardaliye produced from grapes harvested in summer is a good opportunity for consumers who want to eat grapes in winter [2]. Possible probiotic lactic acid bacteria are used in the production of hardaliye, so it makes the drink a more valuable functional product [3]. "Functional Foods" are foods or dietary components that may provide a health benefit beyond basic nutrition. Health can be better controlled through the food choices made knowing that some foods can provide specific health benefits [4].

The nutritional value of hardaliye is derived from the grapes and the fermentation process. Fermentation is one of the oldest methods used in food preservation [5]. Fermented foods are widely consumed in many parts of the world. Microorganisms (bacteria, molds, and yeasts) play an important role in the realization of fermentation processes. Final products have often undergone considerable changes. These changes are not because of only microbial action, but the autolytic process that is brought about by the enzymes which exist in the products [6]. Fermentation enhances the nutritional value of the food through the synthesis of essential amino acids, vitamins, mineral bioavailability, digestibility, detoxification, destruction of phytates, and tannins. Additionally, it provides a wide variety of flavors, aromas, and textures, thus improving organoleptic qualities [7]. Lactic acid bacteria 
play a significant role in the production of many fermented products. As a result of lactic acid fermentation, the acidity, aroma, and texture of the product changes making it more durable and healthier since it prevents the development of pathogenic microorganisms [8]. Fermented foods formed by lactic acid bacteria have negative effects on the cholesterol formation mechanism that is one of the biggest causes of heart disease. Lactic acid bacteria have a positive effect on the immune system. Lactic acid bacteria support immunoglobulin $\mathrm{A}$ and gamma interferon production. This enhances the antitumor activity of lactic acid bacteria. The lactic acid bacteria taken to the digestive tract together with fermented food reduces the activity of enzymes such as the b-glucuronidase, azotoreductase, and nitroreductase in the intestine. Pro-carcinogenic substances are converted to carcinogens with the help of these enzymes [9].

Grapes are rich in phenolic contents. One kilogram of grapes contains 12-15 mg quercetin, less than $2 \mathrm{mg}$ kaempferol, $4.5 \mathrm{mg}$ myricetin, $19 \mathrm{mg}$ catechins, and 1-3 mg coumaric acid [10]. There has been great interest in grape beverages and their products for their potential health benefits due to their impressive antioxidative properties, which are highly correlated with their polyphenol content, including anthocyanins (ACNs) [11]. Red grape juice and wine contains flavonoids at more than $500 \mathrm{mg} / \mathrm{L}$ [12]. Antioxidant flavonoids such as quercetin reduce the oxidation of low density lipoproteins and cell toxication [13]. Dark red grape juice contains about four times more antioxidants than orange and tomato juices [14]. The functionality in human health is supported by the ability of the flavonoids to induce human protective enzyme systems, and by a number of epidemiological studies suggesting protective effects against cardiovascular diseases, cancers, and other age-related diseases [15]. An important effect of flavonoids is the scavenging of oxygen-derived free radicals. In vitro experimental systems also showed that flavonoids possess antiinflammatory, antiallergic, antiviral, and anticarcinogenic properties [16]. Polyphenols are responsible for reducing the risk of neurodegenerative diseases. Resveratrol and flavonoids reduce the risk of arteriosclerosis via inhibition of LDL cholesterol oxidation. They have regulatory effects on blood pressure and blood glucose [7]. Resveratrol is found in the grape skin and seed and therefore is found in grape juice [17]. Resveratrol is synthesized in high amounts, especially in the skin of colorful grapes [18]. Grape skin contains 50-100 mg resveratrol/g. Also, the resveratrol concentration in wine is between 0.2 and $7.7 \mathrm{mg} / \mathrm{L}$ [19]. The content of resveratrol in the grape depends on the grape variety, the degree of maturity, the freshness, and the cleaning conditions [20]. In one study, resveratrol reduced skin tumors in mice by $88 \%$ [21].

Hardaliye provides high antioxidant effects for the human body and prevents oxidative stress so that it can help to inhibit formation of cancer cells. Hardaliye's high antioxidant capacity decreases plasma lipidperoxidation parameters and serum homocysteine concentrations due to its phenolic content [7]. Health benefits of hardaliye are also related to etheric oils present in mustard seeds. Research shows Sinigrin, a component of mustard seeds, has been identified as a suppressing agent against carcinogenesis. This effect of hardaliye has increased interest towards this beverage. Hardaliye helps prevent coronary heart disease and aid digestion systems in addition to its nutritional value [22]. Mustard oils have medicinal effects on common cold, circulatory disorders, and bronchitis, as well as antimicrobial properties [7]. Allyl isothiocyanate is obtained from the mustard seeds. Based on in vitro experiments and animal models, allyl isothiocyanate exhibits many desirable attributes of a cancer chemopreventive agent [23].

One glass gives $170 \mathrm{kcal}$ energy and contains $39 \mathrm{~g}$ carbohydrates. Because its palatable, nonalcoholic, salt-free, non-dairy, and low-fat characteristics it can be consumed by children, vegetarians, people with dairy intolerance, hypertension, and high cholesterol levels [7]. The energy and nutrient composition of hardaliye are shown in Table 1 [24]. Also antioxidant capacity and phenolic compounds of hardaliye are shown in Table 2 [25]. 
Table 1. The energy and nutrient composition of hardaliye.

\begin{tabular}{cccc}
\hline $\begin{array}{c}\text { The Energy and } \\
\text { Nutrient Composition }\end{array}$ & Amount/100 $\mathbf{~ m L}$ & $\begin{array}{c}\text { The Energy and } \\
\text { Nutrient Composition }\end{array}$ & Amount/100 mL \\
\hline Energy (kcal) & 75.54 & Iron $(\mathrm{mg})$ & 0.91 \\
Moisture (g) & 88.51 & Zinc $(\mathrm{mg})$ & 0.24 \\
Ash $(\mathrm{g})$ & 0.23 & Vitamin B1 $(\mathrm{mg})$ & 0.003 \\
Fat (g) & 0.20 & Vitamin B2 $(\mathrm{mg})$ & 0.01 \\
Total dietary fiber $(\mathrm{g})$ & 0.98 & Vitamin B6 $(\mathrm{mg})$ & 0.05 \\
Carbohydrates $(\mathrm{g})$ & 17.53 & Niacin $(\mathrm{mg})$ & 0.31 \\
Fructose $(\mathrm{g})$ & 9.51 & Vitamin C $(\mathrm{mg})$ & 0.24 \\
Glucose $(\mathrm{g})$ & 9.43 & Folate $(\mu \mathrm{g})$ & 1.01 \\
Total Sugar $(\mathrm{g})$ & 18.91 & Pantothenic acid $(\mathrm{mg})$ & 0.08 \\
Potassium $(\mathrm{mg})$ & 94.14 & Magnesium $(\mathrm{mg})$ & 13.59 \\
Calcium $(\mathrm{mg})$ & 13.45 & Phosphorus $(\mathrm{mg})$ & 24.50 \\
\hline
\end{tabular}

Table 2. Antioxidant capacity and phenolic compounds of hardaliye.

\begin{tabular}{cccc}
\hline Composition & Hardaliye & Composition & Hardaliye \\
\hline ORAC $\left(\mathrm{mmol} \mathrm{TE} \mathrm{L}^{-1}\right)$ & $64.0 \pm 5.30$ & Syringic acid $\left(\mathrm{mg} \cdot \mathrm{L}^{-1}\right)$ & $40.9 \pm 1.15$ \\
Total phenolics $\left(\mathrm{mg} \mathrm{GAE} \mathrm{L}^{-1}\right)$ & $2128 \pm 188.09$ & $p$-Coumaric acid $\left(\mathrm{mg} \cdot \mathrm{L}^{-1}\right)$ & $21 \pm 1.71$ \\
Total anthocyanins $\left(\mathrm{mg} \mathrm{C3GE} \mathrm{L} \mathrm{L}^{-1}\right)$ & $41.7 \pm 4.38$ & $o$-Coumaric acid $\left(\mathrm{mg} \cdot \mathrm{L}^{-1}\right)$ & $43.7 \pm 5.77$ \\
trans-Resveratrol $\left(\mathrm{mg} \cdot \mathrm{L}^{-1}\right)$ & $2.72 \pm 0.28$ & Gentisic acid $\left(\mathrm{mg} \cdot \mathrm{L}^{-1}\right)$ & $45.1 \pm 1.22$ \\
Quercetin $\left(\mathrm{mg} \cdot \mathrm{L}^{-1}\right)$ & $65.5 \pm 0.37$ & Ferulic acid $\left(\mathrm{mg} \cdot \mathrm{L}^{-1}\right)$ & $4.09 \pm 2.85$ \\
Total phenolic acids $\left(\mathrm{mg} \cdot \mathrm{L}^{-1}\right)$ & $397 \pm 13.78$ & Sinapic acid $\left(\mathrm{mg} \cdot \mathrm{L}^{-1}\right)$ & $21.9 \pm 0.55$ \\
Gallic acid $\left(\mathrm{mg} \cdot \mathrm{L}^{-1}\right)$ & $47 \pm 0.89$ & Salicylic acid $\left(\mathrm{mg} \cdot \mathrm{L}^{-1}\right)$ & $2.96 \pm 0.17$ \\
Protocatechuic acid $\left(\mathrm{mg} \cdot \mathrm{L}^{-1}\right)$ & $111 \pm 1.42$ & Caffeic acid $\left(\mathrm{mg} \cdot \mathrm{L}^{-1}\right)$ & $60 \pm 1.15$ \\
\hline
\end{tabular}

Values are mean $\pm \mathrm{SD}(n=2)$. ORAC, oxygen radical absorbance capacity; TE, Trolox equivalent; GAE, gallic acid equivalent; C3GE, cyanidin-3-glucoside equivalent.

\section{Hardaliye Production}

Hardaliye is a lactic acid fermented traditional beverage produced from grape juice and crushed grapes with the addition of different concentrations of whole/ground or heat-treated mustard seeds and sour cherry leaves. The color of hardaliye reflects the original color of the grapes [26]. It is known that color intensities of hardaliye change widely depending on grape varieties and production methods $[22,27,28]$. Dark red grapes are preferred. Benzoic acid is used as preservative during production. Benzoic acid inhibits or decreases alcohol production by affecting the yeast. Hardaliye has a characteristic aroma.

The grapes can be contaminated with various microorganisms including different kinds of yeasts, molds, and bacteria before and after harvesting. Grape microflora can differ depending on increasing maturity and changing environmental conditions [29]. This natural microbiota plays a major role in the production of hardaliye [2].

Production of hardaliye is done when the grape harvest starts on October or November. After grapes are washed and crushed, put preferably into wooden (oak) or plastic barrels with a tap over $10 \mathrm{~cm}$ of bottom, and then $0.2 \%$ of crushed raw black mustard seeds (Brassica nigra (L.) Koch) (Ground mustard seeds are weighed and put in cloth bag. The bag is heated to $50{ }^{\circ} \mathrm{C}$ in a small amount of grape juice to reveal the active substance, and then left for cooling) and $0.1 \%$ of benzoic acid is added. The use of mustard seeds and benzoic acid will prevent alcohol fermentation that can be carried out by the yeast in the grape. In order to enhance aroma, crushed cherry leaves (Prunus cerasus L.) can be mixed with black mustard seeds. Since grapes are fermented with their skins, there are transitions of some particles from skins to the drink during production. There should be some space left in the fermentation barrel considering the swell. The lid of the barrel should be half-open. After fermentation starts, the juice is recirculated twice every other day, then the mix is left to ferment at room temperature for 7-10 days. If the temperature is low, the fermentation time is longer (two or three weeks) $[4,26]$. If bitterness caused by the mustard seeds is more than enough to prevent hardaliye consumption, 
water is added to hardaliye [30]. After fermentation is complete, the juice is filtered and bottled. Once fermented, the hardaliye is stored at $4{ }^{\circ} \mathrm{C}$ for three to four months.

The hardaliye is consumed either fresh or aged. If it is aged, hardaliye may contain alcohol [4,26]. Hardaliye is relatively rich in aroma compounds. While some aroma compounds are formed during the must fermentation, many of them transferred from the peels of grapes and mustard seeds during manufacture. Flavor of hardaliye develops in three stages. In the first stage, the flavor becomes strong and bitter because of the fermentation. Then, the biological degradation of mustard seeds finishes and the strong and bitter flavor tends to disappear. Finally, the flavor of hardaliye converts and appears similar to must. Although the flavor development of hardaliye is not presented clearly, the transformation of glucosinolate to allyl isothiocyanate which is a sulphur compound by enzymatic activity of myrosinase is thought to be important in the characteristic flavor of hardaliye [31]. The formation of hardaliye's flavor occurs after 30 days.

The mustard seeds' etheric oils block forming alcohol by inhibition of yeast growth. In addition, this compound helps to create the special flavor of hardaliye [4]. Allyl isothiocyanate can be obtained from the seeds of black mustard (Brassica nigra) or brown Indian mustard (Brassica juncea). When these mustard seeds are broken, the enzyme myrosinase is released and acts on a glucosinolate known as sinigrin to give allyl isothiocyanate [32]. If there is water in the environment, sinigrin in the composition of black mustard seeds is hydrolyzed by the enzyme myrosinase. Allyl isothiocyanate occurs as a result of hydrolysis. It has a bitter taste and is volatile [33]. Moreover, tocopherols contained in mustard help to protect without the bitterness produced by mustard seeds. This feature increases the shelf life of product [34].

One study reported that the myrosinase enzyme activity of Brassica nigra was optimum at $\mathrm{pH} 7$ and $55^{\circ} \mathrm{C}$, and ground mustard seeds have a higher enzymatic activity [35]. In another study, enzyme activity was found to have increased after ground mustard seeds with a small amount of juice were heated to $40-50{ }^{\circ} \mathrm{C}$, cooled, and then added to the juice [36].

The antibacterial effect of mustard seeds on the E. coli O157:H7 serotype, a food borne pathogen, has also been reported in other studies [1], one of which showed that the antibacterial effect of allyl isothiocyanate on E. coli O157:H7 occurs at low $\mathrm{pH}$ values [37]. Having a low $\mathrm{pH}$ value, hardaliye is a suitable product for allyl isothiocyanates to reveal their antibacterial effect.

Allyl isothiocyanates have been found to completely inhibit the development of certain mold species: such as Aspergillus flavus, Penicillium commune, Penicillium corylophilum, Penicillium discolor, Penicillium polonicum, and Penicillium roqueforti [38].

Due to the contribution of black mustard seeds to both the taste and aroma of hardaliye and their superior inhibitory effect, black mustard seeds (Brassica nigra (L.) Koch) may be more suitable for the production of hardaliye. White mustard seeds (Brassica alba (L.) Boiss) can be also used in this process. The active ingredient of the volatile oil is allyl isothiocyanate. Black mustard essential oil includes a ratio $0.40 \%-1.80 \%$ allyl isothiocyanate. White mustard seed contains very little volatile oil [39]. Black and brown mustard essential oils contain $0.40 \%-1.80 \%$ and $0.33 \%-0.44 \%$ of allyl isothiocyanate, respectively [40].

Since small scale local technologies are still effectively used in the production technology of hardaliye, the current related literature presents the traditional production techniques and also different methods aiming to develop the current technology. Some studies have been conducted on the production of various types of hardaliye using different varieties of grape and different concentrations of mustard seed and chemicals, aromatized with various additives-such as sour cherry tree leaves, cloves, and ginger-as well as starter culture additives [41].

\section{Studies Carried out on Hardaliye}

In a research, Guven and Aksoy [33] investigated the effect of different spices on physicochemical properties of hardaliye. Hardaliye was produced using Verigo variety (reddish color and coarse grape particles) of grapes. In the first sample, $2.5 \mathrm{~g}$ mustard seeds; in the second sample, $2 \mathrm{~g}$ mustard 
seeds $+1 \mathrm{~g}$ cloves; in the third sample and $2 \mathrm{~g}$ mustard seeds $+1.5 \mathrm{~g}$ ginger to $1 \mathrm{~L}$ of grape juice were added. The fermentation was continued for 21 days. The $\mathrm{pH}$ values of modified hardaliye are similar to traditional production of hardaliye. The $\mathrm{pH}$ value of the first sample changed from 4.02 (3rd day) to 3.94 (21st day). The $\mathrm{pH}$ values of cloves or ginger added to hardaliye samples changed from 4.06 (3rd day) to 3.91 (21st day) and 4.11 (21st day), respectively. At the end of fermentation, the ginger-added hardaliye had the lowest titratable acidity value $(4.14 \%)$. Similar results were found for cloves-added and traditionally-produced hardaliye in terms of titratable acidity, brix, and reducing sugar. Color intensities of three different hardaliye were 1.052 for traditional production, 1.425 for clover-added, 1.089 for powdered ginger-added. As a result of sensory analysis, the most enjoyable samples in terms of smell and taste were cloves-added hardaliye, ginger-added hardaliye, and traditionally-produced hardaliye, respectively.

In a study carried out by Aydogdu et al. [1], two different hardaliye beverages were produced using Alphonse Lavallée grape variety that has a red color and aromatic properties; and Papazkarası that is blue-black grape variety. Grape pomace- $500 \mathrm{~g}$-for colorization, wildblack mustard seeds (Brassica nigra (L.), 2\%), $25 \mathrm{~g}$ of sour cherry tree leaves (Prunus cerasus L.), $25 \mathrm{mg} / \mathrm{L}$ sulfur as potassium metabisulfite, $0.25 \mathrm{~g}$ sodium benzoate, and $0.25 \mathrm{~g}$ potassium sorbate were added into $10 \mathrm{~L}$ jars and topped up with grape juice and left to ferment (during the 29 days) at room temperature. The same method as with Alphonse Lavallée grapes was used with the Papazkarasi grapes except that the potassium metabisulfite was not added and the mustard seed concentration was $1 \%$. For the tests conducted with the samples containing the Alphonse Lavallée grape variety, the lowest LAB counts were found on second day (LAB; $\left.1.03 \log \mathrm{cfu} \cdot \mathrm{mL}^{-1}\right)$. Increasing after second day, the highest LAB count was seen on 10th day $\left(8.30 \mathrm{log} \mathrm{cfu} \cdot \mathrm{mL}^{-1}\right)$. The number of bacteria started to decrease following the days when the maximum values were obtained. LAB counts for the Papazkarasi grape variety also showed a parallel increase and decrease. LAB counts were $6.1 \log \mathrm{cfu} \cdot \mathrm{mL}^{-1}$ in the juice, decreased to their lowest value on second day of fermentation. Then these values started to increase and reached the highest value on 12 th day with the LAB being $7.4 \log \mathrm{cfu} \cdot \mathrm{mL}^{-1}$. Following 12 th day, the values decreased until 29th day when they were the same as the values obtained from juice. Although coliform group bacteria were found in the juice, they were not detected in any of the samples during the production process of the hardaliye. Moreover, E. coli was not observed in the juice or hardaliye samples. The yeast and mold in juice (Alphonse Lavallée) could not be detected following three days of fermentation. In contrast to the hardaliye produced from the Alphonse Lavallée grapes, the amount of yeasts and molds was higher in the Papazkarası grape variety and they survived for a longer time. In the hardaliye sample produced from Alphonse Lavallee grapes, the $\mathrm{pH}$ value in the juice was 4.24 and total acidity was $2.80 \mathrm{~g} / \mathrm{L}$. These values were 3.79 and $11.93 \mathrm{~g} / \mathrm{L}$ on 29th day of fermentation, respectively. There was no significant change in the Brix (17.0) and the reducing sugar content $(13.11 \%)$ measured in the juice $(p>0.5)$. In the Papazkarasi hardaliye, the total acidity in the juice was higher $(5.93 \mathrm{~g} / \mathrm{L})$ and $\mathrm{pH}$ was 3.82 . On 29 th day, the $\mathrm{pH}$ and the total acidity were measured as 3.73 and $11.4 \mathrm{~g} / \mathrm{L}$, respectively. Similar to the Alphonse Lavallée hardaliye samples, there was no significant difference $(p>0.05)$ in the papazkarasi samples in terms of the brix in the juice (18.0) and the reducing sugar content throughout the fermentation process $(\sim 16 \%)$. For both grape varieties' hardaliye samples, alcohol was below the detection limit of $0.01 \% v / v$.

Hardaliye was produced from Papazkarasi blue-black grapes by conventional method by Askin et al. [42]. After having been exposed to lactic acid fermentation, it was bottled and then stored at $+4{ }^{\circ} \mathrm{C}$ and $20^{\circ} \mathrm{C}$ for 60 days. The analyses were carried out in prepared beverage within the 15, 30, 45, and 60 days of storage. The results of color parameters obtained show the highest proportion of red color in the samples at the beginning $(\mathrm{dA} \%=94.87)$. As expected, the brown color increased with storage time and the highest value was determined for 60 days depending on the storage temperature. Storage under $4{ }^{\circ} \mathrm{C}$ and $20^{\circ} \mathrm{C}$ resulted in $60 \%$ and $78 \%$ losses in anthocyanin content, respectively. The losses of anthocyanin during storage at higher temperature were accompanied by increased polymeric color values and other color parameters, which indicates that anthocyanins 
were also extensively polymerized. For example, phenol compositions were also analyzed using LC-MS/MS system. It was revealed that malvidin-3-O-glucoside was the predominant anthocyanin and also hardaliye has high amounts of resveratrol. A high content of total phenolic (1743 $\pm 8.67 \mathrm{mg}$ of gallic acid equivalents $\left.\mathrm{L}^{-1}\right)$ and antioxidant activity value $\left(8.53 \mathrm{mM}\right.$ Troloks $\left.\mathrm{mL}^{-1}\right)$ is present in fresh beverages. There was significant decrease in total phenols during storage, irrespective of temperature.

Coskun and Arici [43] investigated the effects of the use of different mustard seeds and grape varieties on some properties of hardaliye. Different varieties of grapes (Muscat Hamburg as black grape, Madame Jean Mathias as red grape, Muscat Otonel as white grape) and mustard seeds $(0.1 \%$ black Brassica nigra (L.) Koch, $0.15 \%$ white Brassica alba (L.) Boiss) were used to produce hardaliye samples, and some properties of hardaliye samples were determined during fermentation at room temperature (initially, the first, third, and seventh days). Final $\mathrm{pH}$ values of hardaliye samples containing black and white mustard seeds were 3.54 and 3.58 in samples with black grapes, 3.16 and 3.20 in samples with red grapes, while $\mathrm{pH}$ values were 3.81 and 3.86 in samples with white grapes, respectively. Invert sugar content changed from $19.35 \%$ to $17.79 \%$ in samples with red grapes and black mustard seeds, from $19.35 \%$ to $16.21 \%$ in samples with white mustard seeds, and from $15.00 \%$ to $14.28 \%$ in samples with black grapes and both mustard seeds. Insignificant change was observed for hardaliye samples containing white grapes. The difference in invert sugar contents of hardaliye samples produced with different mustard seeds during fermentation was statistically insignificant. Although there was no significant difference in total mesophilic aerobic bacteria counts and lactic acid bacteria counts of hardaliye samples containing black mustard seeds, change in the yeast and mold counts of these samples was statistically significant. Due to the contribution of black mustard seeds to both taste and aroma of hardaliye and their superior inhibitory effect, it was decided that black mustard seeds may be more suitable for the production of hardaliye.

Altay [44] determined physicochemical properties of hardaliye. The total phenolic contents of two different commercially available hardaliye samples were found as 1.67 and $1.76 \mathrm{mg} \mathrm{GA} / \mathrm{g}$, respectively. These results are very similar to total phenolic content of wines. According to the results, hardaliye samples have $20-21^{\circ}$ Brix values, $\mathrm{pH} 4.05-3.85$, and $70.5 \%-68.4 \%$ water contents, respectively. Their ash, total sugar contents and densities were $2.76 \%-2.63 \%, 2.90-3.12 \mathrm{~g} / \mathrm{L}$, and $1.0853-1.0953$, respectively. Generally, the physicochemical properties of hardaliye are very close to the values of wine and some fruit juices.

Askın and Ozcan [45] determined volatile organic compounds (VOC) formed with lactic acid fermentation in hardaliye by GC-MS. Hardaliye was produced by using a purple-black grape variety called 'Papazkarasi' sourced from Kirklareli. Their main goal was to verify the volatile organic compounds (VOCs) profile of hardaliye produced by using the Papazkarasi grape variety, considering changes induced by storage temperature. For this purpose, the bottles filled with samples were stored with $4{ }^{\circ} \mathrm{C}$ and $20^{\circ} \mathrm{C}$ for two months. There were determined significantly reduction ratios for n-nonanol, pyranone, dodecene, and hydroxymethylfurfural in storage periods. Besides, some volatile organic compounds VOCs are benzene, ethylbenzene, toluene, and $o: m: p$-xylene were determined by GC-MS with this method. There were significant differences between different storage temperatures for the compounds of the samples stored at $20^{\circ} \mathrm{C}$ and $4{ }^{\circ} \mathrm{C}$.

Gulcu and Gungor [46] investigated the effect of fining agents on some bioactive properties of hardaliye. Hardaliye made from Papazkarasi grapes according to traditional methods. Manually pressing to separate from the marc, obtained turbid hardaliye. At this stage, hardaliye clarification was conducted by adding fining agents such as bentonite, gelatin, and pectolytic enzyme into hardaliye individually and in triple combination, with an unclarified sample as the control. Compared with the control sample, total phenolic content, total flavonoids, total anthocyanin, antioxidant capacity (DPPH and ABTS) values decreased in all fining practices. Lowest total phenolic, anthocyanin content and antioxidant capacity (DPPH) was found in the triple combination and bentonite methods. While the most losses in the amount of total flavonoids was in the enzyme method; with regard to total phenolics, total flavonoids, anthocyanins and antioxidant capacity (DPPH and ABTS) values the gelatin method 
and the control sample were found to be significantly closest. In the present study, total anthocyanin concentration of samples highly correlated with CIE $a^{*}$ value, additionally, compared with the control sample CIE $L^{*}$ and $b^{*}$ values increased with the fining process of hardaliye.

Vardar et al. [47] investigated some physicochemical and bioactive properties of hardaliye. The $\mathrm{pH}$ and titratable acidity value of sample were found as 3.76 and 11.89, respectively. Moreover, it was determined that the brix degree of tested sample was 20.5 at $24{ }^{\circ} \mathrm{C}$. According to results of color analysis, $L^{*}, a^{*}$, and $b^{*}$ values were determined to be $17.80,2.72$, and -0.04 , respectively. In addition, water activity of the tested sample was identified as 0.942 . Besides, the phenolic content of the sample found as $3528.5 \mathrm{mg} / \mathrm{L}$.

Hardaliye is stored at $4{ }^{\circ} \mathrm{C}$ for three to four months. This short period limits the industrial production of hardaliye. The application of non-thermal innovative membrane technologies such as osmotic distillation (OD) for the concentration of the fruit juices allows very high concentrations (above $65^{\circ}$ Brix) to be reached under atmospheric pressure and temperatures near ambient temperature. In order to promote year-round storage of hardaliye, Yilmaz and Onsekizoglu Bagci [48] investigated potential use of osmotic distillation for concentration of hardaliye. An aqueous solution can be concentrated by an osmotic gradient using an aqueous osmotic agent with low water activity. The osmotic agent selected was a concentrated $\mathrm{CaCl}_{2}$ solution. A capillary membrane module was used in this process. Osmotic distillation yielded a concentration of hardaliye (with an initial TSS of $21.1^{\circ}$ Brix), supplied from a local market, up to $62.7^{\circ}$ Brix in $330 \mathrm{~min}$.

Arici and Coskun [4] investigated some properties of 26 aged hardaliye samples. The $\mathrm{pH}$ value of hardaliye produced according to traditional method ranged from 3.21 to 3.97; red color (Hunter Lab aL value) of samples ranged from 1.33 to 9.66 . It was reported that the total mesophilic aerobic bacteria counts ranged from $3.5 \times 10^{2}$ to $8 \times 10^{5} \mathrm{cfu} \cdot \mathrm{mL}^{-1}$. The lactic acid bacteria counts of the samples were found to be between $1.0 \times 10^{2}$ and $4.0 \times 10^{4} \mathrm{cfu} \cdot \mathrm{mL}^{-1}$. L. paracasei subsp. paracasei and L. casei subsp. pseudoplantarum were predominantly followed by L. pontis, L. brevis, L. acetotolerans, L. sanfranciscensis (formerly known as Lactobacillus sanfrancisco), and L. vaccinostercus. Yeasts and molds, which were found in 21 samples out of 26 , ranged from $1.0 \times 10^{2}$ to $8.1 \times 10^{4} \mathrm{cfu} \cdot \mathrm{mL}^{-1}$. Coliforms and E. coli were found in none of the samples.

In a study conducted by Coskun and Arici [26], hardaliye was produced by modification of the traditional method and investigated for some properties. Lactobacillus sanfrancisco (LB16), Lactobacillus acetotolerans (LB21), Lactobacillus pontis (LB26), Lactobacillus paracasei ssp. paracasei (LB30) as starter cultures were added into pasteurized grape juice. Production of hardaliye using either white or black mustard seeds with Lactobacillus paracasei ssp. paracasei LB30 reached a minimum $\mathrm{pH}$ value. It was determined that lactobacilli, which was added as starter cultures, and mustard seeds had no clear effect on decrease in total sugar contents. During the seven-day fermentation period, lactic acid bacteria count in hardaliye, produced using white mustard seeds, changed from 4.60, 4.69, 4.47 and $4.79 \log \mathrm{cfu} \cdot \mathrm{mL}^{-1}$ to $4.92,4.94,5.90$, and $6.83 \mathrm{log} \mathrm{cfu} \cdot \mathrm{mL}^{-1}$ respectively and in the other samples, produced using black mustard seeds changed from $4.25,4.07,4.07$, and $4.20 \log \mathrm{cfu} \cdot \mathrm{mL}^{-1}$ to $6.60,7.20$, 6.54, and $6.77 \log \mathrm{cfu} \cdot \mathrm{mL}^{-1}$, respectively.

Coskun et al. [41], compared some properties of the traditional hardaliye with hardaliye which was produced by pasteurized $\left(70{ }^{\circ} \mathrm{C}, 30 \mathrm{~min}\right)$ grape juice with inoculating Lactobacillus plantarum as a starter. Hardaliye samples were produced using black grapes from Malatya region's grape varieties. At the end of fermentation (10 days), $\mathrm{pH}$ value and acidity, the total phenolic compounds, monomeric anthocyanins (malvidin-3-O-glucoside), total tannin, and volatile acid of traditional hardaliye sample were 4.42 and $3.6 \mathrm{~g} / \mathrm{L}, 1392.5 \mathrm{mg} / \mathrm{L}, 114.1 \mathrm{mg} / \mathrm{L}, 1.7 \mathrm{~g} / \mathrm{L}$, and $0.25 \mathrm{~g} / \mathrm{L}$ respectively. The same properties of a hardaliye sample produced by pasteurized grape juice with inoculating starter culture were 4.37, $5.2 \mathrm{~g} / \mathrm{L}, 2837.5 \mathrm{mg} / \mathrm{L}, 229.1 \mathrm{mg} / \mathrm{L}, 3.0 \mathrm{~g} / \mathrm{L}$, and $0.28 \mathrm{~g} / \mathrm{L}$, respectively. At the end of fermentation, the total mesophilic aerobic bacteria, the lactic acid bacteria and yeast and mold counts of traditional hardaliye sample were $4.7 \times 10^{4} \mathrm{cfu} \cdot \mathrm{mL}^{-1} ; 3.4 \times 10^{4} \mathrm{cfu} \cdot \mathrm{mL}^{-1}$ and $1.2 \times 10^{4} \mathrm{cfu} \cdot \mathrm{mL}^{-1}$, respectively. The total mesophilic aerobic bacteria and the lactic acid bacteria counts of other hardaliye 
sample were $3 \times 10^{5} \mathrm{cfu} \cdot \mathrm{mL}^{-1}$ and $2.1 \times 10^{5} \mathrm{cfu} \cdot \mathrm{mL}^{-1}$. Yeast and mold were not detected. Hardaliye samples were packaged in glass bottles and later pasteurized. These samples were kept in cold weather $\left(4{ }^{\circ} \mathrm{C}\right)$ for a period of one year and again a year later were analyzed [3]. At the end of storage, $\mathrm{pH}$ value and acidity, the total phenolic compounds, monomeric anthocyanins (malvidin-3-O-glucoside), total tannin, and volatile acid of traditional hardaliye sample were $4.11,5.8 \mathrm{~g} / \mathrm{L}, 1102.5 \mathrm{mg} / \mathrm{L}, 44.6 \mathrm{mg} / \mathrm{L}$, and $0.24 \mathrm{~g} / \mathrm{L}$, respectively. The same properties of another sample were 4.01, 7.0 g/L, 2727.5 mg/L, $109.1 \mathrm{mg} / \mathrm{L}$, and $0.39 \mathrm{~g} / \mathrm{L}$. As a result of sensory analysis, traditional hardaliye was admired more than the other.

Coskun [49] investigated effect to hardaliye of the use of different lactic acid bacteria. L. plantarum and L. pentosus were individually and mixed inoculated as starter cultures into the crushed grapes pasteurized. The highest total phenolic and total anthocyanin content were determined in hardaliye samples that produced using Siyah Uzum (Black Grape) and inoculated with L. plantarum on the 10th day. $\mathrm{pH}$ and volatile acid content were higher than others in samples inoculated L. plantarum. Except samples inoculated L. plantarum, the amount of reducing sugars showed a tendency to the lowest values of reducing sugars were determined in control samples. The lactic acid bacteria counts decreased according to the count at the beginning of fermentation at 10th day. L. plantarum has been most effective starter culture on the properties of hardaliye. The transfer of some compounds from grape pulp into grape must (mostly from the skin) increase with the use of starter culture.

In one study, Coskun et al. [50], investigated changes in some properties of hardaliye samples produced using different lactic acid bacteria during fermentation process. Cabernet Sauvignon as the grape variety was used. Some properties of hardaliye samples were determined during fermentation at room temperature (initial, the 1st, $3 \mathrm{rd}, 7 \mathrm{th}, 10 \mathrm{th}$ and 21 st days). Grape juice was pasteurized at $85^{\circ} \mathrm{C}$ for $30 \mathrm{~min}$. Hardaliye samples were inoculated with Lactobacillus plantarum and Lactobacillus pentosus as starter into the pasteurized grape juice. A significant $\mathrm{pH}$ change was not observed in the control samples since the grape juice was pasteurized. Maximum $\mathrm{pH}$ and titration acidity were observed in the samples inoculated with L. pentosus and L. plantarum + L. pentosus.

A maximum decrease in invert sugar content was seen in hardaliye sample inoculated with L. plantarum + L. pentosus. The minimum decrease in total phenolic content was seen in the sample inoculated with L. pentosus. The maximum decrease in total phenolic content was noticed in the sample inoculated with L. plantarum and in the control sample. Maximum increase in volatile acid was seen in the sample inoculated with L. plantarum + L. pentosus. The number of lactic acid bacteria in the sample inoculated with L. plantarum had the highest increase compared to other samples during fermentation. The number of lactic acid bacteria in the sample inoculated with L. pentosus had the lowest increase. The population of lactic acid bacteria in the samples inoculated with L. plantarum, L. pentosus, and L. plantarum + L. pentosus changed from $1.5 \times 10^{5}$ to $1.55 \times 10^{7}$; from $5.3 \times 10^{5}$ to $1.8 \times 10^{6}$; and from $4.2 \times 105$ to $8 \times 10^{6} \mathrm{cfu} \cdot \mathrm{mL}^{-1}$, respectively. The lactic acid bacteria growth was not observed in control samples. Yeast and mold were not noticed in any of samples. The most remarkable samples in terms of color were the samples inoculated with L. plantarum and L. plantarum + L. pentosus. In terms of appearance, sample inoculated with L. plantarum + L. pentosus had the highest score. In terms of the smell and taste, the control sample had the highest score.

Hardaliye had no antimicrobial effect on A. brassillesis and S. cerevisiae. Most significant antimicrobial effect on $E$. coli was hardaliye by forming a $20 \mathrm{~mm}$ inhibition zone. The antimicrobial effect of hardaliye on bacteria is E. coli $(20 \mathrm{~mm})>$ total coliform $(10 \mathrm{~mm})>$ total bacteria $(9 \mathrm{~mm})>$ L. monocytogenes $(9 \mathrm{~mm})$ [51].

The antioxidative effects of the traditional grape-based beverage, hardaliye, were investigated with a 40-day randomized controlled clinical trial on 89 healthy adults by Amoutzopoulos et al. [25]. Subjects were randomly divided into three groups: high hardaliye $(\mathrm{HH})$, low hardaliye (LH), and a control group. $\mathrm{HH}$ and $\mathrm{LH}$ groups consumed $500 \mathrm{~mL}$ and $250 \mathrm{~mL}$ hardaliye per day, respectively, and the control group did not consume any hardaliye. Dien conjugate (DC), malondialdehyde (MDA), vitamin $\mathrm{C}$, total antioxidant capacity (TAC), and homocysteine concentrations were measured in 
fasting blood samples collected at baseline and after intervention. Significant decreases in DC, MDA, and homocysteine concentrations were observed in HH and LH groups $(p<0.001)$ after intervention, whereas the control group showed no change. The reduction in homocysteine was significantly different between HH and LH groups $(p<0.001)$, except for DC and MDA. TAC and vitamin C were slightly increased; however, the change was not statistically significant. Dietary supplementation with hardaliye affects the MDA, DC, and homocysteine levels in blood, possibly due to the presence of antioxidant compounds. Dose response was only observed for homocysteine.

\section{Suggestions}

It is produced in a limited number of provinces with non-standard methods. A standard method should be determined to increase the shelf life of this product that is valuable due to probiotic properties. Pasteurization might be considered for longer shelf life. For a long shelf life and standard product, studies should be done on starter cultures. A new process should be designed taking into account issues such as suitable grape type, selection of suitable starter culture to be used in hardaliye production, pasteurization norms, storage conditions, and storage time. There should be more research about this nutritious traditional drink in order to produce it industrially. Hardaliye produced with traditional methods at home, which is very healthy and nutritious and has relatively short shelf life (three months), can be industrialized and its shelf life can be extended. The development, increase, and diversity of technological production is possible with the development of traditional methods by the help of scientific research. If a small scale producer succeeds in the production of hardaliye with starter culture, it might be adapted to large scale production.

\section{Conclusions}

Consumers are showing an increased demand for healthy foods. Hardaliye, a traditional Turkish beverage, could be considered healthy food due to its probiotic properties, thus it could be an alternative response to consumer demand. Even with its healthy properties, home-made production is common. Industrial production is just in small-scale at present and it must be developed. By this way, hardaliye will become a more preferable beverage. More studies are required to determine the characteristic properties of hardaliye and their effects. Identification of the product properties will allow improvements for its industrial production.

Conflicts of Interest: The author declares no conflicts of interest.

\section{References}

1. Aydogdu, H.; Yildirim, S.; Halkman, A.K.; Durgun, T. A study on production and quality criteria of hardaliye; a traditional drink from Thrace Region of Turkey. Gida 2014, 39, 139-145. (In Turkish)

2. Coskun, F. A traditional fermented beverage. Hasad Gida 2005, 21, 22-25. (In Turkish)

3. Coskun, F.; Arici, M.; Celikyurt, G.; Gulcu, M. Changes occuring at the end of storage in some properties of hardaliye produced by using different methods. J. Tekirdag Agric. Fac. 2012, 9, 62-67. (In Turkish)

4. Aric1, M.; Coskun, F. Hardaliye: Fermented grape juice as a traditional Turkish beverage. Food Microbiol. 2001, 18, 417-421. [CrossRef]

5. Naidu, A.S.; Bidlack, W.R.; Clemens, R.A. Probiotic spectra of lactic acid bacteria (LAB). Crit. Rev. Food Sci. Nutr. 1999, 39, 13-126. [CrossRef] [PubMed]

6. Wang, H.L.; Hesseltine, C.W. Use of microbiological cultures: Legume and cereal products. Food Technol. 1981, 35, 79-83.

7. Aktac, S.; Haskoylu, A.; Gunes, E. Nutritional properties of hardaliye. In Proceedings of the 3rd International Symposium on Traditional Foods from Adriatic to Caucasus, Sarajevo, Bosnia and Herzegovina, 1-4 October 2015.

8. Piergiovanni, L. Packaging and shelf life of fermented foods. Ital. J. Food Sci. 2012, 24, 9-15.

9. Turantas, F. Microorganisms that play a role in fermentation. In Food Microbiology, 2nd ed.; Unluturk, A., Turantas, F., Eds.; Mengi Tan Printing Hause: Izmir, Turkey, 1998; pp. 433-453. (In Turkish) 
10. Shahidi, F.; Naczk, M. Food Phenolics, Chemistry, Effects, Applications; Technomic: Lancaster, PA, USA, 1995.

11. Gil, M.I.; Tomas-Barberan, F.A.; Hess-Pierce, B.; Holcroft, D.M.; Kader, A.A. Antioxidant activity of pomegranate juice and its relationshipwith phenolic composition and processing. J. Agric. Food Chem. 2000, 48, 4581-4589. [CrossRef] [PubMed]

12. Gulcu, M.; Demirci, A.S.; Guner, K.G. Black grape; Its rich nutritional content and its importance for health. In Proceedings of the Turkey 10th Food Congress, Erzurum, Turkey, 21-23 May 2008. (In Turkish)

13. Luzia, M.R.; da Paixão, K.C.C.; Marcilio, R.; Trugo, L.C.; Quinteiro, L.M.C.; de Maria, C.A.B. Effect of 5-caffeoylquinic acid on soybean oil oxidative stability. Int. J. Food Sci. Technol. 1997, 32, 15-19. [CrossRef]

14. Carper, J. 10 Foods for Longevity Science Says These 10 Can Help You Live Longer Better; Weekend, Gannet Company: McLean, VA, USA, 1999.

15. Yao, L.H; Jiang, Y.M; Shi, J.; Tomas-Barber, F.A; Datta, N.; Singanusong, R.; Chen, S.S. Flavonoids in food and their health benefits. Plant Food Hum. Nutr. 2004, 59, 113-122. [CrossRef]

16. Middleton, E., Jr. Effect of plant flavonoids on immune and inflammatory cell function. Adv. Exp. Med. Biol. 1998, 439, 175-182. [PubMed]

17. Guerrero, R.F.; Puertas, B.; Fernández, M.I.; Piñeiro, Z.; Cantos-Villar, E. UVC-treated skin-contact effect on both white wine quality and resveratrol content. Food Res. Int. 2010, 43, 2179-2185. [CrossRef]

18. Keskin, N.; Noyan, T.; Kunter, B. Health from grapes with resveratrol. Turk. Clin. 2009, 29, $1273-1279$. (In Turkish)

19. Aggarwal, B.B.; Shishodia, S. Resveratrol in Health and Disease; CRC Press, Taylor \& Francis Group: Boca Raton, FL, USA, 2006.

20. Feijoo, O.; Moreno, A.; Falque, E. Content of trans- and cis-resveratrol in Galician white and red wines. J. Food Compos. Anal. 2008, 21, 608-613. [CrossRef]

21. Geoffrey, C.; Davis, A.; Springen, K.; Underwood, A. Cancer \& diet. Newsweek 1988, 132, 40-46.

22. Prado, F.C.; Parada, J.L.; Pandey, A.; Soccol, C.R. Trends in non-dairy probiotic beverages. Food Res. Int. 2008, 41, 111-123. [CrossRef]

23. Zhang, Y. Allyl isothiocyanate as a cancer chemopreventive phytochemical. Mol. Nutr. Food Res. 2010, 54, 127-135. [CrossRef] [PubMed]

24. Amoutzopoulos, B. Effects of a Traditional Fermented Grape-Based Drink "Hardaliye" on a Variety of Biochemical and Antioxidant Parameters in Healthy Adults. Ph.D. Thesis, Hacettepe University Institute of Health Sciences, Ankara, Turkey, 2013.

25. Amoutzopoulos, B.; Loker, G.B.; Samur, G.; Cevikkalp, S.A.; Yaman, M.; Kose, T.; Pelvan, E. Effects of a traditional fermented grape-based drink "hardaliye" on antioksidant status of healthy adults: A randomized controlled clinical trial. J. Sci. Food Agric. 2013, 93, 3604-3610. [CrossRef] [PubMed]

26. Coskun, F.; Arici, M. The effects of using different mustard seeds and starter cultures on some properties of hardaliye. Ann. Microbiol. 2006, 56, 335. [CrossRef]

27. Kılıc, O.; Copur, O.U. Quality criteria of hardaliyes produced from some grape varieties. In Proceedings of the Turkey 3th Viticulture Symposium, Bursa, Turkey, 31 May-3 June 1988. (In Turkish)

28. Unal, M.U.; Sener, A.; Sen, K.; Yllmaztekin, M. Seasonal variation in amino acid and phenolic compound profiles of three Turkish white wine grapes. Turk. J. Agric. For. 2015, 39, 984-991. [CrossRef]

29. Canbas, A. Microorganisms in the production of beer, wine and high alcohol drinks. Gida 1986, 11, $283-288$. (In Turkish)

30. Karlıbag Hardaliye. Available online: http://www.trakyadankapiniza.com/karlibaghardaliye (accessed on 6 October 2016). (In Turkish)

31. Erbay, P.S.; Sonmezdag, A.S.; Amanpour, A.; Selli, S. Aroma compounds of a Turkish traditional beverage: Hardaliye. In Proceedings of the 3rd International Symposium on Traditional Foods from Adriatic to Caucasus, Sarajevo, Bosnia and Herzegovina, 1-4 October 2015.

32. Allyl-Isothiocyanate. Available online: http://en.wikipedia.org/wiki/Allyl_isothiocyanate (accessed on 10 October 2016).

33. Guven, S.; Aksoy, M. Some modifications in mustard production. In Proceedings of the 2nd Traditional Foods Symposium, Van, Turkey, 27-29 May 2009; pp. 675-678. (In Turkish)

34. Mustard. Available online: http://www.minndak.com/mustard.htm (accessed on 15 November 2016).

35. Stoin, D.; Pirsan, P.; Radu, F.; Poian, M.A.; Alexa, E.; Dogaru, D. Studies regarding the myrosinase enzymatic activity from black mustard (Brassica nigra) seeds. J. Food Agric. Environ. 2009, 7, 44-47. 
36. Incedayı, B.; Tamer, C.E.; Senkoyuncu, A.; Copur, O.U. Research into the determination of the effect of different black grape varieties on hardaliye production. In Proceedings of the 1st International Symposium on Traditional Foods from the Adriatic to the Caucasus, Tekirdag, Turkey, 15-17 April 2010; pp. 1044-1047. (In Turkish)

37. Luciano, F.B.; Holley, R.A. Enzymatic inhibition by allyl isothiocyanate and factors affecting its antimicrobial action against Escherichia coli O157:H7. Int. J. Food Microbiol. 2009, 131, 240-245. [CrossRef] [PubMed]

38. Nielsen, P.V.; Rios, R. Inhibition of fungal growth on bread by volatile components from spices and herbs, and the possible application in active packaging, with special emphasis on mustard essential oil. Int. J. Food Microbiol. 2000, 60, 219-229. [CrossRef]

39. Coskun, F.; Tirpanci Sivri, G. Hardaliye: A beverage produced by the fermentation of grape juice. Curr. Opin. Biotech. 2013, 24 (Suppl. 1), S97. [CrossRef]

40. Alpozen, E. Isothiocyanate compounds. Gida Yem Analiz 35 2011, 9, 36-37. (In Turkish)

41. Coskun, F.; Arici, M.; Gulcu, M.; Celikyurt, G. Some physicochemical, microbiological and sensory properties of hardaliyes produced by different methods. In Proceedings of the 2nd Traditional Foods Symposium, Van, Turkey, 27-29 May 2009; pp. 665-669. (In Turkish)

42. Askın, B.; Atik, A. Color and antioxidant properties of fermented grape beverage under different storage conditions. Turk. J. Agric. For. 2016. [CrossRef]

43. Coskun, F.; Arici, M. Effect of the use of different mustard seeds and grape varieties on some properties of hardaliye. Acad. Food J. 2011, 9, 6-11.

44. Altay, F. Physicochemical properties of hardaliye. In Proceedings of the 2nd International Symposium on Traditional Foods from Adriatic to Caucasus, Struga (Ohrid Lake), Macedonia, 24-26 October 2013.

45. Askin, B.; Ozcan, C. Determination of volatile organic compounds (VOC) formed with lactic acid fermentation in hardaliye by GC-MS. In Proceedings of the 3rd International Symposium on Traditional Foods from Adriatic to Caucasus, Sarajevo, Bosnia and Herzegovina, 1-4 October 2015.

46. Gulcu, M.; Gungor, T.A. The effect of fining agents on some bioactive properties of hardaliye. In Proceedings of the 3rd International Symposium on Traditional Foods from Adriatic to Caucasus, Sarajevo, Bosnia and Herzegovina, 1-4 October 2015.

47. Vardar, U.S.; Tekin, Z.H.; Ozcelik, G. Physicochemical and bioactive properties of hardaliye. In Proceedings of the 3rd International Symposium on Traditional Foods from Adriatic to Caucasus, Sarajevo, Bosnia and Herzegovina, 1-4 October 2015.

48. Yilmaz, E.; Onsekizoglu Bagci, P. Concentration of hardaliye by osmotic distillation process. In Proceedings of the 3rd International Symposium on Traditional Foods from Adriatic to Caucasus, Sarajevo, Bosnia and Herzegovina, 1-4 October 2015.

49. Coskun, F. Effect to hardaliye of the use of different lactic acid bacteria. In Proceedings of the 2 nd International Symposium on Traditional Foods from Adriatic to Caucasus, Struga (Ohrid Lake), Macedonia, 24-26 October 2013.

50. Coskun, F.; Gulcu, M.; Tirpanci Sivri, G. Changes in some properties of hardaliye samples produced using different lactic acid bacteria during fermentation process. In Proceedings of the 3rd International Symposium on Traditional Foods from Adriatic to Caucasus, Sarajevo, Bosnia and Herzegovina, 1-4 October 2015.

51. Pehlivanoglu, H.; Gunduz, H.H.; Ozulku, G.; Demirci, M. An investigation of antimicrobial activity of wheat grass juice, barley grass juice, hardaliye and boza. Int. Interdiscip. J. Sci. Res. 2015, 2, 8-14.

(c) 2017 by the author; licensee MDPI, Basel, Switzerland. This article is an open access article distributed under the terms and conditions of the Creative Commons Attribution (CC-BY) license (http://creativecommons.org/licenses/by/4.0/). 